Article

\title{
High photocatalytic activities of zinc oxide nanotube arrays modified with tungsten trioxide nanoparticles
}

\author{
Yawen Li, Yuzhen Bu, Qian Liu, Xia Zhang, Junli Xu * \\ College of Science, Northeastern University, Shenyang 110004, Liaoning, China
}

\section{A R T I C L E I N F}

\section{Article history:}

Received 9 July 2017

Accepted 12 November 2017

Published 5 January 2018

\section{Keywords:}

Zinc oxide nanotube

Tungsten trioxide

Photocatalytic degradation

Electrodeposition

Electronic property

\begin{abstract}
A B S T R A C T
Well-aligned zinc oxide ( $\mathrm{ZnO})$ nanotube arrays loaded with tungsten trioxide $\left(\mathrm{WO}_{3}\right)$ nanoparticles were synthesized by a process involving chemical bath deposition in combination with pyrolysis. The prepared $\mathrm{ZnO}-\mathrm{WO}_{3}$ composites were characterized by X-ray diffraction, energy dispersive spectrometer, field emission scanning electron microscopy, X-ray photoelectron spectroscopy, photoluminescence spectroscopy, Fourier transform infrared spectroscopy and UV-vis diffuse reflectance spectroscopy. The photocatalytic activities of the $\mathrm{ZnO}-\mathrm{WO}_{3}$ composite photocatalysts with different $\mathrm{WO}_{3}$ contents for the degradation of the herbicide chlorinated phenoxyacetic acid (MCPA-Na) under simulated sunlight irradiation were systematically evaluated. It was found that the $\mathrm{WO}_{3}$ content had a great effect on the photocatalytic activity of the $\mathrm{ZnO}-\mathrm{WO}_{3}$ composites. The composite with $3 \% \mathrm{WO}_{3}$ showed the highest photocatalytic activity, with a degradation rate of chlorinated phenoxyacetic acid of $98.5 \%$ after $200 \mathrm{~min}$ with $20 \mathrm{mg}$ of photocatalyst. This photodegradation rate was about twice that of the pristine $\mathrm{ZnO}$ nanotube array. The recombination of photogenerated electrons and holes was increasingly suppressed with the addition of $\mathrm{WO}_{3}$ to $\mathrm{ZnO}$. The high relative content of defects on the surface of the $\mathrm{ZnO}-\mathrm{WO}_{3}$ composites was beneficial to their photocatalytic activity in the degradation of chlorinated phenoxyacetic acid.
\end{abstract}

(C) 2018, Dalian Institute of Chemical Physics, Chinese Academy of Sciences. Published by Elsevier B.V. All rights reserved.

\section{Introduction}

Chlorinated phenoxyacetic acid (denoted MCPA-Na) is one of the oldest and most readily available herbicides in the world, and is widely used as a weed killer on cereal crops, pasture, and orchards. However, MCPA-Na is considered potentially dangerous to both animals and humans and is a well-known endocrine disruptor [1]. The biodegradability of MCPA-Na is extremely low and it has been detected as a major contaminant in effluents released into both subterranean and superficial water bodies [2].

Semiconductor-assisted photocatalysis can complement conventional approaches to degrade or transform hazardous chemical waste $[3,4]$. Zinc oxide $(\mathrm{ZnO})$ is one of the most extensively studied semiconductor photocatalysts because it is environmentally friendly, cheap, and has a large exciton binding energy [4-7]. Various morphologies of $\mathrm{ZnO}$ including nanorods $[8,9]$, nanotubes [10], hollow nanospheres [11], nanoplates [12], and nanoflower-like structures $[13,14]$ have been prepared. In particular, the "one-dimensional" tubular morphology of $\mathrm{ZnO}$ has attracted interest because of its special hollow structure and large surface area, which are crucial for optimizing the performance of dye-sensitized solar cells, sensors, and hydrogen devices [15-18]. Moreover, the "one-dimensional" morphology can facilitate transport of charge carriers and minimize the loss of charge carriers at grain boundaries

\footnotetext{
* Corresponding author. Tel/Fax: +86-24-83684533; E-mail: jlxu@mail.neu.edu.cn

This work was supported by the National Natural Science Foundation of China (51574071).

DOI: 10.1016/S1872-2067(17)62977-2 | http://www.sciencedirect.com/science/journal/18722067 | Chin. J. Catal., Vol. 39, No. 1, January 2018
} 
$[19,20]$.

Most reported $\mathrm{ZnO}$ nanotubes are wide-band-gap semiconductors and can only absorb ultraviolet (UV) light. Therefore, it is necessary to functionalize $\mathrm{ZnO}$ nanotubes so that they absorb the visible component of sunlight. Coupling a narrow-band-gap semiconductor with a wide-band-gap semiconductor is a useful approach to capture visible light because the coupling of different semiconductor oxides can narrow the band gap of the resulting composite. Moreover, higher photocatalytic activity may be achieved for semiconductor composites because electron-hole pairs maybe separated efficiently under irradiation. It has been reported that the construction of heterostructures is an effective strategy to improve photocatalytic performance [21-23].

Tungsten trioxide $\left(\mathrm{WO}_{3}\right)$ is a promising photocatalyst that has an appropriate band gap of $2.8 \mathrm{eV}$ to enable absorption in the visible region, stable physicochemical properties, and high resistance to photocorrosion $[24,25]$. It has been reported that the coupling of $\mathrm{ZnO}$ nanoparticles with $\mathrm{WO}_{3}$ resulted in composites with higher photocatalytic activity than those of pristine $\mathrm{ZnO}$ and pristine $\mathrm{WO}_{3}$ [26-30]. However, the photocatalytic properties of $\mathrm{ZnO}$ nanotubes loaded with $\mathrm{WO}_{3}$ have not been reported yet. Therefore, we decided to couple $\mathrm{WO}_{3}$ nanoparticles with $\mathrm{ZnO}$ nanotube arrays in the present work. ZnO nanotube arrays are first synthesized by electrodeposition. Composites with different contents of $\mathrm{WO}_{3}$ are obtained by the addition of ammonium metatungstate hydrate $\left(\left(\mathrm{NH}_{4}\right)_{6} \mathrm{H}_{2} \mathrm{~W}_{12} \mathrm{O}_{40}\right.$. $\mathrm{XH}_{2} \mathrm{O}$ ) to the prepared $\mathrm{ZnO}$ nanotube arrays and annealing at $450{ }^{\circ} \mathrm{C}$ in air for $2 \mathrm{~h}$. The photocatalytic properties of the prepared $\mathrm{ZnO}-\mathrm{WO}_{3}$ nanotube arrays with different contents of $\mathrm{WO}_{3}$ nanoparticles are evaluated by their ability to degrade MCPA-Na. Based upon the results of activity evaluation and characterization, a photocatalytic mechanism for the composites is proposed.

\section{Experimental}

\subsection{Synthesis of $\mathrm{ZnO}$ nanotubes and $\mathrm{ZnO}-\mathrm{WO}_{3}$ arrays}

Electrodeposition of $\mathrm{ZnO}$ nanotubes was carried out in a conventional three-electrode cell using a Pt electrode with an area of about $3.0 \mathrm{~cm}^{2}$ as the auxiliary electrode. The working electrode was indium tin oxide (ITO)-coated glass with a sheet resistance of $6-8 \Omega / \mathrm{cm}^{2}$. A saturated $\mathrm{Ag} / \mathrm{AgCl}$ electrode was used as the reference electrode. The ITO glass substrate with dimensions of $3 \times 4 \mathrm{~cm}$ was cleaned ultrasonically in distilled water, ethanol, acetone, and 6 vol\% hydrochloric acid in sequence for $5 \mathrm{~min}$ each, and then rinsed in distilled water before electrodeposition. $\mathrm{ZnO}$ crystal seeds were grown on the ITO substrate in solution containing $0.02 \mathrm{~mol} / \mathrm{L}$ zinc nitrate $\left(\mathrm{Zn}\left(\mathrm{NO}_{3}\right)_{2}\right), 0.013 \mathrm{~mol} / \mathrm{L}$ ammonium acetate $\left(\mathrm{CH}_{3} \mathrm{CO}_{2} \mathrm{NH}_{4}\right)$, and $0.01 \mathrm{~mol} / \mathrm{L}$ hexamethylenetetramine $\left(\mathrm{C}_{6} \mathrm{H}_{12} \mathrm{~N}_{4}\right)$ under a cathodic voltage of $-1.8 \mathrm{~V}$ (vs. $\mathrm{Ag} / \mathrm{AgCl}$ ) for $300 \mathrm{~s}$ at $90{ }^{\circ} \mathrm{C}$. The cathodic voltage was switched to $-1.2 \mathrm{~V}$ to prepare the $\mathrm{ZnO}$ nanorod arrays. After electrodeposition for $60 \mathrm{~min}$ at this applied potential, a uniform white film was obtained. The film was washed with distilled water and then used as the working electrode in $0.07 \mathrm{~mol} / \mathrm{L} \mathrm{C}_{2} \mathrm{H}_{4}\left(\mathrm{NH}_{2}\right)_{2}$ at $-0.2 \mathrm{~V}$ for $60 \mathrm{~min}$ at $70{ }^{\circ} \mathrm{C}$ to prepare pristine $\mathrm{ZnO}$ nanotube arrays.

To prepare $\mathrm{ZnO}-\mathrm{WO}_{3}$ nanotube arrays, the required amount of $\left(\mathrm{NH}_{4}\right)_{6} \mathrm{H}_{2} \mathrm{~W}_{12} \mathrm{O}_{40} \cdot \mathrm{XH}_{2} \mathrm{O}$ was first dispersed in acetone. The solution was added dropwise onto the prepared $\mathrm{ZnO}$ nanotube surface. The substrate was annealed in a muffle furnace at 450 ${ }^{\circ} \mathrm{C}$ in air for $2 \mathrm{~h}$. The composite fabrication process is illustrated in Fig. 1. All reagents used in this study were of analytical grade and used directly without any purification. The obtained $\mathrm{ZnO}-\mathrm{WO}_{3}$ samples are denoted as $\mathrm{ZnO}-\mathrm{WO}_{3}(2 \%, 3 \%$, or $5 \%)$ according to their $\mathrm{W} / \mathrm{Zn}$ molar ratio of $2 \%, 3 \%$, and $5 \%$, respectively, in the precursor solution. For comparison, annealed pristine $\mathrm{ZnO}$ nanotube arrays were prepared under the same conditions without the addition of $\left(\mathrm{NH}_{4}\right)_{6} \mathrm{H}_{2} \mathrm{~W}_{12} \mathrm{O}_{40} \cdot \mathrm{XH}_{2} \mathrm{O}$. Pristine $\mathrm{WO}_{3}$ powder was also prepared by calcination of $\left(\mathrm{NH}_{4}\right)_{6} \mathrm{H}_{2} \mathrm{~W}_{12} \mathrm{O}_{40} \cdot \mathrm{XH}_{2} \mathrm{O}$ at $450{ }^{\circ} \mathrm{C}$ in air for $2 \mathrm{~h}$ in a muffle furnace.

\subsection{Characterization}

The crystal structures of the prepared $\mathrm{ZnO}$ and $\mathrm{ZnO}-\mathrm{WO}_{3}$ nanotube arrays were characterized by X-ray diffraction (XRD) using a PANalytical B.V. MPDDY2094 X-ray diffractometer (Almelo, the Netherlands) with $\mathrm{Cu} K_{\alpha}$ radiation $(\lambda=1.5406 \AA)$. Scanning electron microscopy (SEM) images and quantitative standard microanalyses were obtained using a Zeiss ultra plus field-emission scanning electron microscope (Germany) (FE-SEM) equipped with energy-dispersive X-ray spectrometer (EDS) analysis apparatus. High-resolution transmission elec-



Fig. 1. Schematic illustration of the fabrication process of the $\mathrm{ZnO}-\mathrm{WO}_{3}$ nanotube arrays. 
tron microscopy (HRTEM) images were captured using a Tecnai $G^{2} 20$ microscope (FEI, USA) at an accelerating voltage of $200 \mathrm{kV}$. UV-vis diffuse reflectance spectroscopy (DRS) was recorded on a Perkin Elmer Lambda $35 \mathrm{UV}$-vis spectrophotometer (Wellesley, USA) using $\mathrm{BaSO}_{4}$ as a reference over the scan range of 200-800 nm. Photoluminescence (PL) measurements were performed on a Hitachi F7000 fluorescence spectrophotometer (Japan) with an excitation wavelength of $325 \mathrm{~nm}$ at room temperature. Mott-Schottky (MS) measurements were performed in $0.5 \mathrm{~mol} / \mathrm{L} \mathrm{Na}_{2} \mathrm{SO}_{4}$ solution using an electrochemical workstation (CHI660E, China) with a three-electrode system at room temperature. The obtained $\mathrm{ZnO}, \mathrm{WO}_{3}$, and $\mathrm{ZnO}-\mathrm{WO}_{3}$ nanotube array samples served as the working electrode. A Pt plate and saturated $\mathrm{Ag} / \mathrm{AgCl}$ were used as the counter and reference electrodes, respectively. Fourier transform infrared (FTIR) spectra were measured using a Thermo Scientific Nicolet IS10 spectrometer (USA) over the scan range from 400 to $4000 \mathrm{~cm}^{-1}$ using $\mathrm{KBr}$ disks. X-ray photoelectron spectroscopy (XPS) was performed on a Thermo Scientific ESCALAB 250Xi spectrometer (USA) with an $\mathrm{Al} K_{\alpha}$ excitation source.

\subsection{Photocatalytic activity tests}

The photocatalytic activities of the samples were evaluated by the degradation of MCPA-Na aqueous solution under simulated sunlight irradiation. In each experiment, the sample was put into water $(100 \mathrm{~mL})$ containing MCPA-Na $(20 \mathrm{mg})$. A $300-W$ xenon lamp with a power density of $20.15 \mathrm{~mW} / \mathrm{cm}^{2}$ (Beijing Science and Technology Co, Ltd., Park Philae) was set inside a cylindrical reactor and surrounded by a circulating water jacket to cool the lamp and minimize infrared radiation. UV-Vis spectroscopy was used to determine the solution concentration of residual MCPA-Na at room temperature (TU-1900, Beijing Purkinje General Instrument Co, Ltd.). The absorbance accuracy was \pm 0.002 Abs (0-0.5 Abs) and \pm 0.004 Abs (0.5-1.0 Abs). The total organic carbon (TOC) remaining in the solution after the photodegradation process was measured using a Jena Multi C/N 3100 analyzer.

\section{Results and discussion}

\subsection{Morphology and structure characterization}

Fig. 2 shows the microstructure of the obtained $\mathrm{ZnO}$ and $\mathrm{ZnO}-\mathrm{WO}_{3}(3 \%)$ nanotube arrays. The pristine $\mathrm{ZnO}$ nanotubes (Fig. 2(a)) possess a hollow hexagonal structure with an internal diameter of $400 \mathrm{~nm}$ and thickness of $80 \mathrm{~nm}$. The pristine $\mathrm{ZnO}$ nanotubes have a smooth surface. The $\mathrm{ZnO}$ nanotubes after loading $\mathrm{WO}_{3}$ (Fig. 2(b)) have a smaller internal diameter than that of the pristine $\mathrm{ZnO}$ nanotubes. The elemental maps of $\mathrm{ZnO}-\mathrm{WO}_{3}(3 \%)$ recorded by EDS are shown in Fig. 2(c-e). These elements are all distributed uniformly on the surface. Element contents of the samples are listed in Table 1. Only Zn and $\mathrm{O}$ were detected in the pristine $\mathrm{ZnO}$ nanotubes. However, the atomic ratio of $\mathrm{Zn}$ to $\mathrm{O}$ was not exactly equal to 1 ; the atomic ratio of $\mathrm{Zn}$ was slightly higher than that of 0 . Table 1 reveals that the $\mathrm{W}$ contents in $\mathrm{ZnO}-\mathrm{WO}_{3}(2 \%), \mathrm{ZnO}^{-} \mathrm{WO}_{3}$ (3\%), and
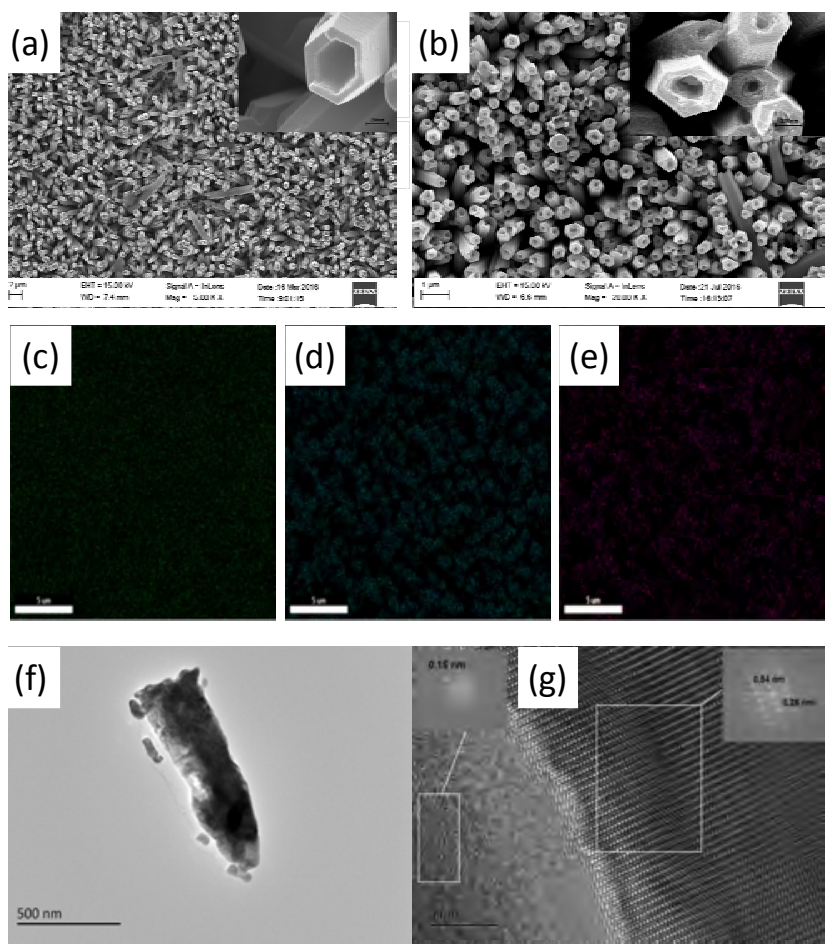

Fig. 2. FESEM images of $\mathrm{ZnO}$ (a) and $\mathrm{ZnO}-\mathrm{WO}_{3}(3 \%)$ (b). (c) Corresponding elemental mapping images of $\mathrm{Zn}, \mathrm{O}$ (d), and $\mathrm{W}$ (e) in $\mathrm{ZnO}^{-\mathrm{WO}_{3}}(3 \%)$. (f) TEM image of $\mathrm{ZnO}-\mathrm{WO}_{3}(3 \%)$. (g) HRTEM image of $\mathrm{ZnO}-\mathrm{WO}_{3}(3 \%)$.

$\mathrm{ZnO}-\mathrm{WO}_{3}(5 \%)$ are 12 at $\%, 11$ at $\%$, and 20 at\%, respectively. Higher $\mathrm{W}$ contents were found in the $\mathrm{ZnO}-\mathrm{WO}_{3}$ samples than present in the precursor solution, indicating that most of the $\mathrm{WO}_{3}$ in solution was loaded on the surface of the $\mathrm{ZnO}$ nanotubes. Moreover, the $\mathrm{W}$ content of $\mathrm{ZnO}-\mathrm{WO}_{3}$ (3\%) was slightly lower than that detected for $\mathrm{ZnO}^{-\mathrm{WO}_{3}}(2 \%)$, indicating more $\mathrm{WO}_{3}$ was inside the $\mathrm{ZnO}$ nanotubes in the $\mathrm{ZnO}-\mathrm{WO}_{3}(3 \%)$ sample than in $\mathrm{ZnO}-\mathrm{WO}_{3}(2 \%)$.

Fig. 2(f) displays a typical TEM image of the $\mathrm{ZnO}-\mathrm{WO}_{3}$ (3\%) sample, which clearly indicates that it has a tubular structure with some substance in the tube and on its surface. Fig. 2(g) shows a HRTEM image of the same sample, in which two single-crystalline phases can distinguished. The insets are the fast Fourier transformation (FFT) of the marked areas. The FFT spots corresponded to the $\left(\begin{array}{llll}1 & 0 & 3\end{array}\right)$ crystalline plane of $\mathrm{ZnO}$ with an interlayer spacing of around $0.15 \mathrm{~nm}$ as well as the $\left(\begin{array}{lll}0 & 1 & 1\end{array}\right)$ and $\left(\begin{array}{lll}2 & 0 & 2\end{array}\right)$ crystalline planes of $\mathrm{WO}_{3}$ with interlayer spacings of around 0.54 and $0.26 \mathrm{~nm}$, respectively.

Fig. 3 shows the XRD patterns of the pristine $\mathrm{ZnO}, \mathrm{WO}_{3}$, and $\mathrm{ZnO}-\mathrm{WO}_{3}$ (3\%) samples. The peaks at $34.422^{\circ}(002), 36.253^{\circ}$

Table 1

Element contents in $\mathrm{ZnO}$ and $\mathrm{ZnO}-\mathrm{WO}_{3}$ samples.

\begin{tabular}{lccc}
\hline \multirow{2}{*}{ Sample } & \multicolumn{3}{c}{ Element content (at\%) } \\
\cline { 2 - 4 } & $\mathrm{Zn}$ & 0 & $\mathrm{~W}$ \\
\hline $\mathrm{ZnO}$ & 53 & 47 & 0 \\
$\mathrm{ZnO}-\mathrm{WO}_{3}(2 \%)$ & 49 & 39 & 12 \\
$\mathrm{ZnO}-\mathrm{WO}_{3}(3 \%)$ & 51 & 38 & 11 \\
$\mathrm{ZnO}-\mathrm{WO}_{3}(5 \%)$ & 44 & 36 & 20 \\
\hline
\end{tabular}






Fig. 3. XRD patterns of pristine $\mathrm{ZnO}, \mathrm{WO}_{3}$, and $\mathrm{ZnO}-\mathrm{WO}_{3}(3 \%)$ samples.

(101), $47.539^{\circ}(102), 56.603^{\circ}(110), 62.864^{\circ}$ (103), 67.963 ${ }^{\circ}$ (112), $69.100^{\circ}(201)$, and $72.562^{\circ}(004)$ were indexed to $\mathrm{ZnO}$ with a hexagonal wurtzite structure (JCPDS Card No. 00-036-1451). The peaks observed at $34.730^{\circ}(020), 23.172^{\circ}$ (002), $24.104^{\circ}(110), 28.341^{\circ}$ (102), $36.292^{\circ}$ (221), $50.726^{\circ}$ (114), and $56.785^{\circ}$ (412) (JCPDS Card No. 01-083-0950 and 01-087-2401) were consistent with monoclinic $\mathrm{WO}_{3}$, indicating that $\mathrm{WO}_{3}$ can be obtained by annealing $\left(\mathrm{NH}_{4}\right)_{6} \mathrm{H}_{2} \mathrm{~W}_{12} \mathrm{O}_{40} \cdot X \mathrm{H}_{2} \mathrm{O}$. No obvious diffraction peaks from $\mathrm{WO}_{3}$ were observed for the $\mathrm{ZnO}-\mathrm{WO}_{3}$ (3\%) sample, which is probably because of its low content of $\mathrm{WO}_{3}$. Because the samples were fabricated on ITO glass substrates, $\mathrm{In}_{2} \mathrm{O}_{3}$ (JCPDS Card No. 03-065-3170), $\mathrm{SnO}_{2}$ (JCPDS Card No. 00-046-1242), and $\mathrm{SiO}_{2}$ (JCPDS Card No. 00-046-1242) were also detected for these samples.

XPS measurements were conducted to obtain insight into the composition of the $\mathrm{ZnO}_{-} \mathrm{WO}_{3}(3 \%)$ sample; the results are shown in Fig. 4. The survey spectrum (Fig. 4(a)) revealed the presence of W, O, and Zn. As illustrated in Fig. 4(b), the W $4 f$ spectrum contains typical $W^{6+}$ peaks at binding energies of 35.4 and $37.5 \mathrm{eV}$, which are very close to the values reported for $\mathrm{WO}_{3}$ [31]. In Fig. 4(c), the Zn $2 p$ peaks at 1022.0 and $1045.2 \mathrm{eV}$ indicated that $\mathrm{Zn}$ existed as $\mathrm{Zn}^{2+}$, which was consistent with the values reported for $\mathrm{ZnO}$ [10]. Figure 4(d) shows that the $01 \mathrm{~s}$ peak can be deconvoluted into two individual peaks at the binding energies of 530.3 and $531.6 \mathrm{eV}$, which correspond to the lattice oxygen of $\mathrm{ZnO}$ and hydroxide $\left(\mathrm{OH}^{-}\right)$, respectively [10].

Fig. 5 presents the FTIR spectra of pristine $\mathrm{ZnO}$ and $\mathrm{ZnO}-\mathrm{WO}_{3}$ samples. The peak at $491 \mathrm{~cm}^{-1}$ is ascribed to the stretching of $\mathrm{Zn}-\mathrm{O}$ bonds [32]. The peak at $1636 \mathrm{~cm}^{-1}$ is assigned to aromatic and $-\mathrm{OH}$ bending vibrations, and the peak at $3428 \mathrm{~cm}^{-1}$ corresponds to the stretching of surface $\mathrm{OH}^{-}$groups [33]. Compared with that of pristine ZnO, the FTIR spectra of the $\mathrm{ZnO}-\mathrm{WO}_{3}$ samples contained new peaks at around 870 and $989 \mathrm{~cm}^{-1}$, which belonged to $\mathrm{W}-\mathrm{O}-\mathrm{W}$ stretching, bending, or lattice modes [34]. Moreover, the peak at $3428 \mathrm{~cm}^{-1}$ for the $\mathrm{ZnO}-\mathrm{WO}_{3}$ composites is stronger than that for pristine $\mathrm{ZnO}$, indicating more $\mathrm{OH}^{-}$groups were present in the $\mathrm{ZnO}-\mathrm{WO}_{3}$


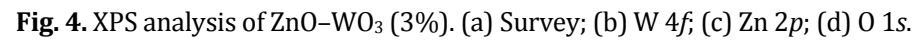




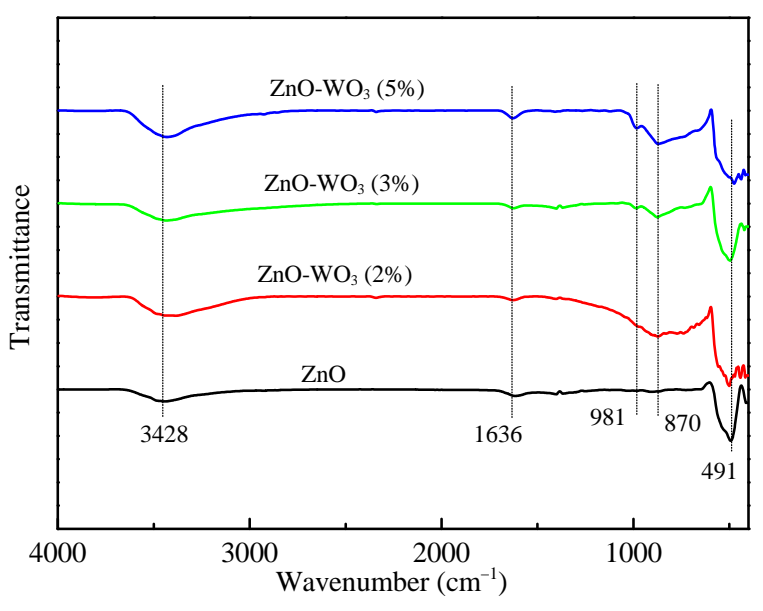

Fig. 5. FTIR spectra of pristine $\mathrm{ZnO}$ and $\mathrm{ZnO}-\mathrm{WO}_{3}$ samples.

composites than in $\mathrm{ZnO}$. It has been reported that a higher amount of $\mathrm{OH}^{-}$groups in the catalyst may result in higher photocatalytic activity because $\mathrm{OH}^{-}$can capture photogenerated holes and transform into reactive hydroxyl radicals [31].

\subsection{Optical properties}

UV-vis DRS is an effective technique to determine the light absorption ability of a semiconductor at different wavelengths. Fig. 6(a) shows the UV-vis DRS obtained for all the samples. Pristine ZnO exhibited strong light absorption from 200 to 420 $\mathrm{nm}$ and little absorption in the visible light range. In comparison, the absorption spectra of the $\mathrm{ZnO}^{-\mathrm{WO}_{3}}$ (3\%) and $\mathrm{ZnO}-\mathrm{WO}_{3}(5 \%)$ composites displayed an apparent, red shift of the band edge, which may be caused by the aggregation of $\mathrm{WO}_{3}$ particles [35]. Fig. 6(a) reveals that the absorption intensity in the visible region increases with the content of $\mathrm{WO}_{3}$ in the $\mathrm{ZnO}-\mathrm{WO}_{3}$ samples, which indicates that the coupling of $\mathrm{WO}_{3}$ with $\mathrm{ZnO}$ can enhance the absorption of $\mathrm{ZnO}$ in the visible-light region. This increased intensity may be attributed to the interaction between $\mathrm{W}^{6+}$ and crystal lattice oxygen resulting in an unsaturated bond and surface vacancy on $\mathrm{ZnO}$ [28].

The optical bandgap of the composites is calculated using the fundamental absorption, which corresponds to electron excitation from the valance band to conduction band. The absorption coefficient $(\alpha)$ is calculated using the Eq. (1):

$$
\alpha=2.303 \mathrm{~A} / \mathrm{d}
$$

where $A$ is the absorbance, and $d$ is the film thickness. The absorption coefficient $(\alpha)$ and the incident photon energy $(h v)$ are related by Eq. (2):

$$
\alpha h v=C\left(h v-E_{\mathrm{g}}\right)^{1 / 2}
$$

where $h, v, C$ and $E_{\mathrm{g}}$ are plank's constant, light frequency, proportionality constant, and the optical band gap, respectively. From the plot of $(\alpha h v)^{2}$ vs. $h v$ (Fig. 6(b)), the band gap energy is obtained by extrapolating the linear portion of the curve to the $h v$ axis. The pristine $\mathrm{ZnO}$ and $\mathrm{WO}_{3}$ exhibited the $E_{\mathrm{g}}$ of 3.15 and $2.8 \mathrm{eV}$, respectively, while the $\mathrm{ZnO}^{-\mathrm{WO}_{3}}(2 \%, 3 \%$, and $5 \%)$ composites displayed narrower $E_{\mathrm{g}}$ of about $2.96,2.85$, and 3.10 $\mathrm{eV}$, respectively. $E_{\mathrm{g}}$ of the $\mathrm{ZnO}-\mathrm{WO}_{3}$ samples initially decreased and then increased with the $\mathrm{WO}_{3}$ content. $\mathrm{ZnO}-\mathrm{WO}_{3}(3 \%)$ possesses the narrowest $E_{\mathrm{g}}$, which indicates that it can absorb more visible light than the other samples.

PL spectroscopy is an effective technique to evaluate the efficiency of charge carrier trapping, transfer, and separation in semiconductor materials and surface defects of samples [36-39]. Fig. 7 shows the room-temperature PL spectra of the ITO-supported $\mathrm{ZnO}$ and $\mathrm{ZnO}-\mathrm{WO}_{3}$ nanotube arrays obtained with an excitation wavelength of $325 \mathrm{~nm}$. The emission at 380 $\mathrm{nm}$ is caused by the recombination of photogenerated electrons and holes [28,40,41]. High PL intensity at $380 \mathrm{~nm}$ is observed for the pristine $\mathrm{ZnO}$ nanotubes sample, indicating the rapid recombination of electrons and holes. The intensities of this emission peak for the $\mathrm{ZnO}-\mathrm{WO}_{3}$ composites are dramatically decreased compared with that of the pristine $\mathrm{ZnO}$ nanotubes. Very weak emission intensity is observed for the $\mathrm{ZnO}^{-} \mathrm{WO}_{3}$ (2\% and $3 \%$ ) photocatalysts, which implies that a large number of photogenerated electrons and holes were trapped and their recombination was prohibited for these samples. Moreover, there is an extra emission peak at $600 \mathrm{~nm}$ for the $\mathrm{ZnO}-\mathrm{WO}_{3}$ ( $2 \%$ and $3 \%$ ) composites. It has been reported that the visible emission peaks at around 420-620 nm observed for $\mathrm{ZnO}$ are related to defects and doubly charged oxygen vacancy states in the nanostructures $[28,42,43]$. The stronger the intensity of this luminescence, the more intrinsic defects (oxygen and zinc vacancies or interstitials) present in the sample [44]. As shown


Fig. 6. (a) UV-vis DRS of pristine $\mathrm{ZnO}, \mathrm{WO}_{3}$, and $\mathrm{ZnO}-\mathrm{WO}_{3}$ samples. (b) Plots of transformed Kubelka-Munk function versus light energy. 


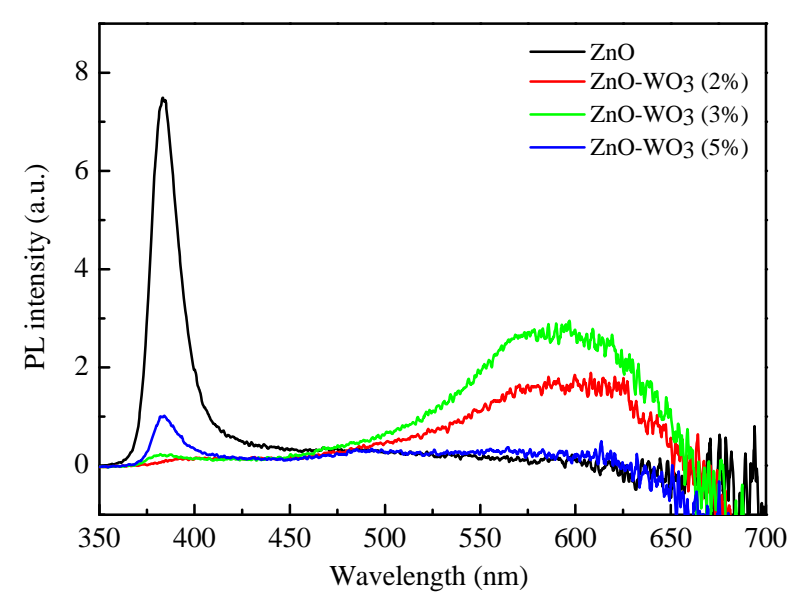

Fig. 7. $\mathrm{PL}$ spectra of pristine $\mathrm{ZnO}$ and $\mathrm{ZnO}-\mathrm{WO}_{3}$ samples.

in Fig. 7, the visible emission peak at $600 \mathrm{~nm}$ is much more intense for the $\mathrm{ZnO}-\mathrm{WO}_{3}$ (2\% and 3\%) samples compared to the case for $\mathrm{ZnO}_{-} \mathrm{WO}_{3}(5 \%)$ and pristine $\mathrm{ZnO}$ samples, which indicates there are more defects in the former two samples than in the latter two samples. It has been reported that surface defects can improve the photocatalytic performance of metal oxide semiconductors because defects can act as charge carrier traps, where the charges are transferred to adsorbed species, preventing the recombination of photogenerated electrons and holes [42].

\subsection{Photocatalytic properties}

Fig. 8(a) depicts the relationship between the MCPA-Na degradation efficiency and irradiation time of the prepared $\mathrm{ZnO}$ nanotubes and $\mathrm{ZnO}-\mathrm{WO}_{3}$ composites. After $200 \mathrm{~min}$ of simulated sunlight irradiation, about 58\% of MCPA-Na was degraded by pristine $\mathrm{ZnO}$ nanotubes, while about $92 \%$, 98.5\%, and $49 \%$ of MCPA-Na was degraded by $\mathrm{ZnO}-\mathrm{WO}_{3}(2 \%), \mathrm{ZnO}^{-\mathrm{WO}_{3}}$ (3\%), and $\mathrm{ZnO}-\mathrm{WO}_{3}(5 \%)$, respectively. Increasing the content of $\mathrm{WO}_{3}$ in $\mathrm{ZnO}$ from $2 \%$ to $3 \%$ effectively enhanced the photodegradation efficiency of the $\mathrm{ZnO}$ nanotubes. However, further increasing the $\mathrm{WO}_{3}$ content had an adverse effect. The TOC contents of MCPA-Na solution were also measured, as shown in Fig. 8(b). The TOC content decreased to almost zero after 200 min of photocatalytic degradation, which means the herbicide pollutant was almost totally removed.

The pseudo-first-order model expressed by the equation $-\ln \left(C / C_{0}\right)=k t$ was used to quantitatively explain the reaction kinetics of MCPA-Na degradation. Here, $C_{0}$ and $C$ are the initial pollutant concentration and pollutant concentration at any time, respectively, $k$ is the pseudo-first-order rate constant, and $t$ is the reaction time. According to this equation, $k$ can be obtained from a linear plot of $-\ln \left(C / C_{0}\right)$ against $t$. The kinetic plots for photocatalytic degradation of MCPA-Na over composites with different $\mathrm{WO}_{3}$ loading are presented in Fig. 8(c) and the calculated $k$ values are shown in Fig. 8(d). The highest $k$ was $0.0148 \mathrm{~min}^{-1}$ for $\mathrm{ZnO}-\mathrm{WO}_{3}(3 \%)$, and it was $0.0145,0.003$, and $0.007 \mathrm{~min}^{-1}$ for $\mathrm{ZnO}-\mathrm{WO}_{3}$ (2\%), $\mathrm{ZnO}-\mathrm{WO}_{3}(5 \%)$, and $\mathrm{ZnO}$, respectively.

Cycling stability is an important factor to evaluate the performance of a photocatalyst. Herein, the cycling stability of the prepared $\mathrm{ZnO}$ and $\mathrm{ZnO}-\mathrm{WO}_{3}$ (3\%) thin films was evaluated. As shown in Fig. 8(e), the pristine $\mathrm{ZnO}$ sample exhibited poor cycling stability. The ZnO photocatalyst achieved 58\% MCPA-Na degradation in the first run, which decreased markedly to $7 \%$ and $6 \%$ in the second and third runs, respectively. This poor
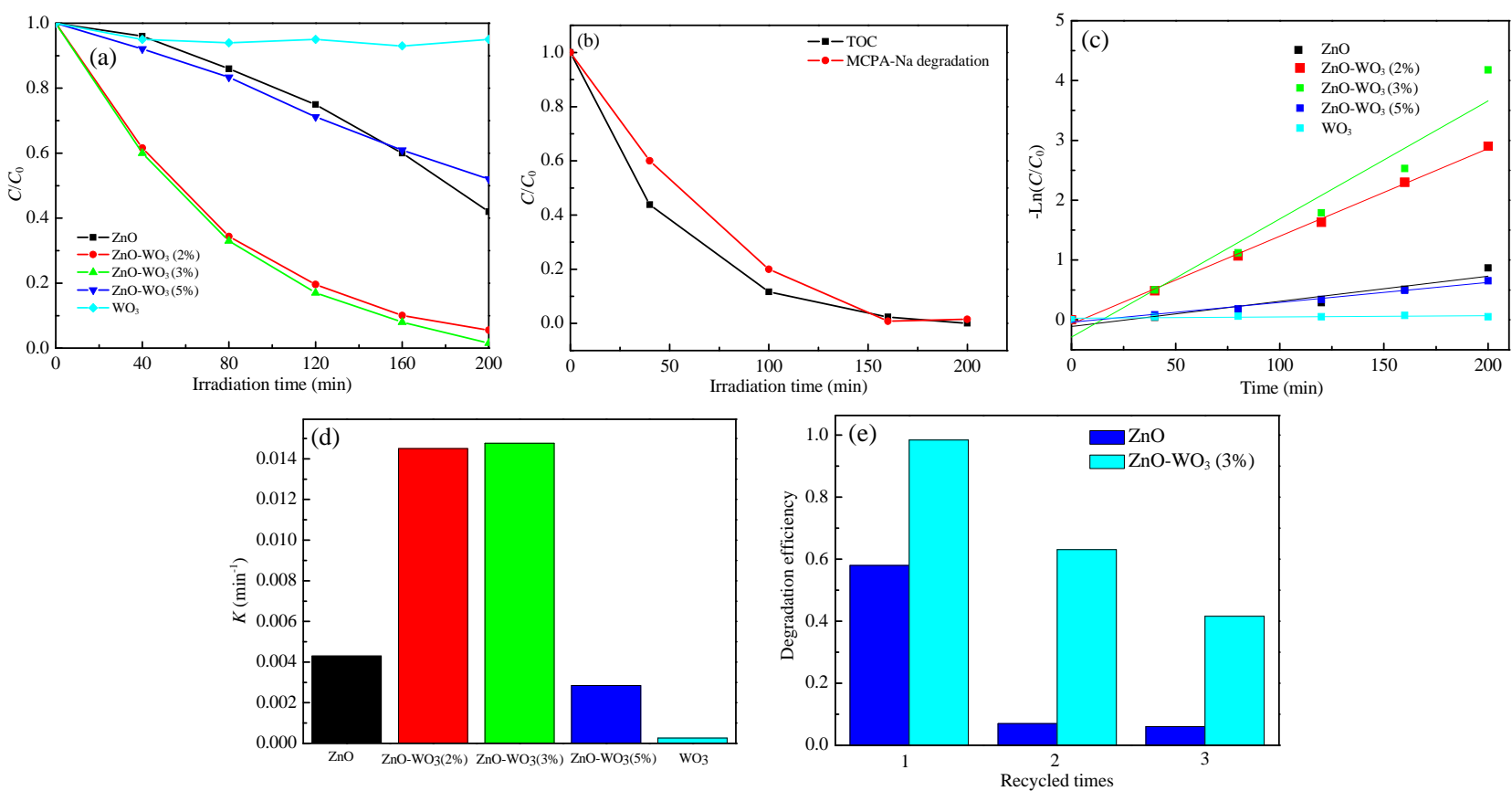

Fig. 8. (a) Photocatalytic degradation of MCPA-Na under simulated sunlight irradiation. (b) Variation of MCPA-Na and TOC concentrations using $\mathrm{ZnO}-\mathrm{WO}_{3}(3 \%)$ as a catalyst. (c) Kinetic plots for the photocatalytic degradation of MCPA-Na. (d) Pseudo-first-order rate constants of MCPA-Na photocatalytic degradation. (e) Reuse of $\mathrm{ZnO}$ and $\mathrm{ZnO}-\mathrm{WO}_{3}(3 \%)$ for photocatalytic degradation of MCPA-Na. 
cycling stability of the $\mathrm{ZnO}$ photocatalyst is mainly caused by

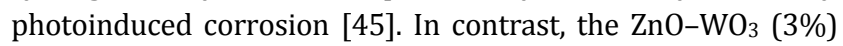
composite degraded $98 \%, 63 \%$, and $41 \%$ of MCPA-Na in the first, second, and third runs, respectively. Thus, photocatalytic stability was improved by the coupling of $\mathrm{WO}_{3}$ with $\mathrm{ZnO}$. However, it still needs to be further improved for practical use of this composite catalyst.

\subsection{Mechanistic study}

The electronic properties of a semiconductor can be investigated by MS analysis of its capacitance measurements. The type of semiconductor can be determined from the plot of $1 / C_{\mathrm{SC}^{2}}$ versus $E$, where $C_{\mathrm{SC}^{2}}$ is the space-charge capacitance and $E$ is the scanning potential. A negative slope indicates a p-type semiconductor, while a positive slope indicates an n-type semiconductor. Moreover, the intercept of a linear plot at $1 / C_{\mathrm{SC}^{2}}=0$ gives the flat band potential $\left(E_{\mathrm{FB}}\right)$. Fig. $9(\mathrm{a})$ shows the MS plots for the $\mathrm{ZnO}-\mathrm{WO}_{3}(3 \%)$ sample at different frequencies. The derived $\mathrm{E}_{\mathrm{FB}}$ were almost the same at different frequencies. Therefore, the capacitance measurements for MS analysis of all samples were collected at $1000 \mathrm{~Hz}$; the results are presented in Fig. 9(b). The slopes of the MS plots are positive for all the samples, indicating their n-type nature. To estimate $\mathrm{E}_{\mathrm{FB}}$, the linear part of each plot was extrapolated to $1 / C_{\mathrm{SC}^{2}}=0$. The $E_{\mathrm{FB}}$ values for $\mathrm{ZnO}, \mathrm{ZnO}^{-\mathrm{WO}_{3}}$ (2\%), $\mathrm{ZnO}-\mathrm{WO}_{3}$ (3\%), $\mathrm{ZnO}-\mathrm{WO}_{3}$ (5\%), and $\mathrm{WO}_{3}$ samples estimated from their MS plots are $-0.23,-0.25$, $-0.46,-0.19$, and $-0.52 \mathrm{~V}$ (vs. $\mathrm{Ag} / \mathrm{AgCl}$ ), respectively. Because the Fermi level of NHE at $25{ }^{\circ} \mathrm{C}$ is $-4.5 \mathrm{eV}$ with respect to the vacuum level [46], the energy positions of band edges on the electrochemical scale can be converted from the values on the absolute vacuum energy scale using Eq. (3):

$$
E_{(\mathrm{NHE})}=-E_{(\mathrm{AVS})}-4.50
$$

The calculated $E_{\mathrm{FB}}$ on the absolute vacuum energy scale for $\mathrm{ZnO}, \mathrm{ZnO}-\mathrm{WO}_{3}$ (2\%), $\mathrm{ZnO}-\mathrm{WO}_{3}$ (3\%), $\mathrm{ZnO}-\mathrm{WO}_{3}$ (5\%), and $\mathrm{WO}_{3}$ are $-4.47,-4.45,-4.24,-4.50$, and $-4.18 \mathrm{eV}$, respectively. Because $E_{\mathrm{FB}}$ lies just below the conduction band (CB) edge energies $\left(E_{\mathrm{c}}\right)$ for n-type semiconductors and just above the valence band (VB) edge energies $\left(E_{\mathrm{v}}\right)$ for p-type semiconductors, it could be assumed that $E_{\mathrm{C}}$ is equal to $E_{\mathrm{FB}}$ for n-type semiconductors. Combined with the results of UV-vis DRS, the $E_{\mathrm{v}}$ values of $\mathrm{ZnO}$ and the $\mathrm{ZnO}-\mathrm{WO}_{3}$ composites were calculated using Eq.
Table 2

Electronic properties of $\mathrm{ZnO}$ and $\mathrm{ZnO}-\mathrm{WO}_{3}$ samples.

\begin{tabular}{lccc}
\hline Semiconductor & $\begin{array}{c}\text { Potential of the } \\
\text { conduction band } \\
(\mathrm{eV})\end{array}$ & $\begin{array}{c}\text { Potential of the } \\
\text { valence band } \\
(\mathrm{eV})\end{array}$ & $\begin{array}{c}\text { Band gap } \\
\text { energy } \\
(\mathrm{eV})\end{array}$ \\
\hline $\mathrm{ZnO}$ & -4.47 & -7.62 & 3.15 \\
$\mathrm{ZnO}-\mathrm{WO}_{3}(2 \%)$ & -4.45 & -7.41 & 2.96 \\
$\mathrm{ZnO}-\mathrm{WO}_{3}(3 \%)$ & -4.24 & -7.09 & 2.85 \\
$\mathrm{ZnO}-\mathrm{WO}_{3}(5 \%)$ & -4.50 & -7.60 & 3.10 \\
$\mathrm{WO}_{3}$ & -4.18 & -6.98 & 2.80 \\
\hline
\end{tabular}

(4); the results are summarized in Table 2.

$$
E_{\mathrm{V}}=E_{\mathrm{C}}-E_{\mathrm{g}}
$$

Based on the positions of the $\mathrm{CB}, \mathrm{VB}$, and $E_{\mathrm{g}}$ of $\mathrm{WO}_{3}$ and $\mathrm{ZnO}$, we speculate that the possible energy storage mechanism of the $\mathrm{ZnO}-\mathrm{WO}_{3}$ composites is as follows (Fig. 9(c)). When $\mathrm{WO}_{3}$ and $\mathrm{ZnO}$ are irradiated with solar light, electrons are excited to the $\mathrm{CB}$, leaving holes in the VB. Because both the bottom of the $\mathrm{CB}$ and top of the $\mathrm{VB}$ of $\mathrm{ZnO}$ are lower than those of $\mathrm{WO}_{3}, \mathrm{ZnO}$ can act as a sink for the photogenerated electrons in the coupled oxides. In addition, the photogenerated holes in $\mathrm{ZnO}$ might be trapped within the $\mathrm{WO}_{3}$ particle, making charge separation more efficient. Therefore, the recombination of the photogenerated carriers is suppressed, leading to an increase in photo-oxidation efficiency. However, if $\mathrm{WO}_{3}$ content of the composite is too high, the dispersion of $\mathrm{WO}_{3}$ becomes poor and the aggregated $\mathrm{WO}_{3}$ can behave as recombination centers, resulting in a decrease in photocatalytic activity.

\section{Conclusions}

$\mathrm{WO}_{3}$ was successfully loaded onto $\mathrm{ZnO}$ nanotube arrays by chemical bath deposition. The addition of $\mathrm{WO}_{3}$ changed the band structure of the $\mathrm{ZnO}$ nanotube arrays, allowing the recombination of photogenerated electrons and holes to be suppressed at a proper loading content of $\mathrm{WO}_{3}$. About $98.5 \%$ of MCPA-Na in solution was degraded by $\mathrm{ZnO}-\mathrm{WO}_{3}$ (3\%) under simulated sunlight irradiation, and the degradation rate of MCPA-Na by $\mathrm{ZnO}-\mathrm{WO}_{3}$ (3\%) was about twice that of the pristine $\mathrm{ZnO}$ nanotube array sample. The high relative content of surface defects on the $\mathrm{ZnO}-\mathrm{WO}_{3}$ composite increased its photocatalytic activity in MCPA-Na degradation.
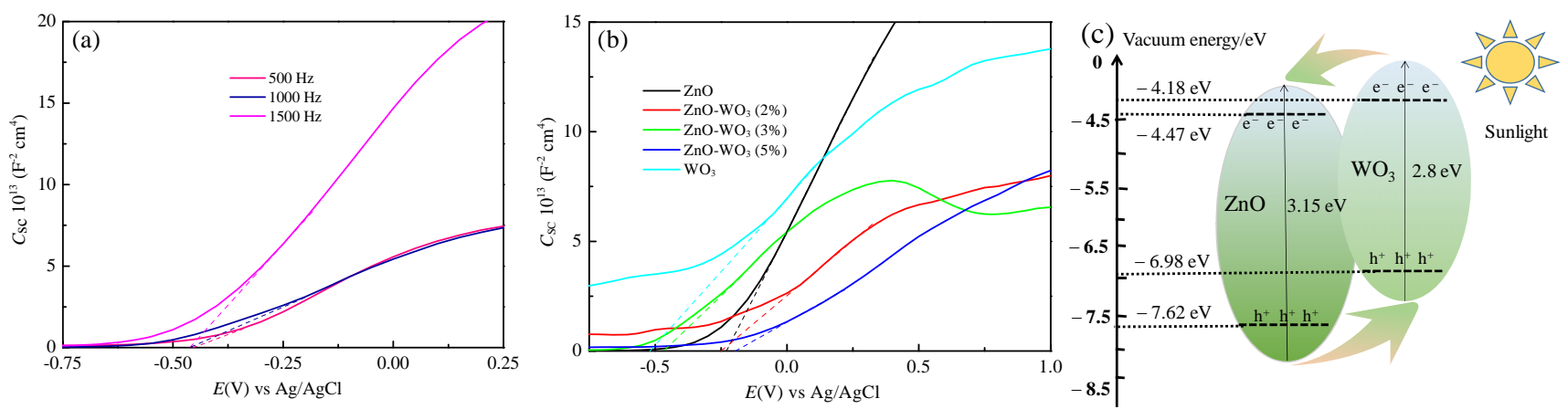

Fig. 9. (a) MS plots of $\mathrm{ZnO}-\mathrm{WO}_{3}(3 \%)$ at frequencies of 500,1000 and $1500 \mathrm{~Hz}$ in $0.5 \mathrm{~mol} / \mathrm{L} \mathrm{Na}_{2} \mathrm{SO}_{4}$ aqueous solution. (b) $\mathrm{MS}$ plots of $\mathrm{ZnO}, \mathrm{WO}_{3}$, and $\mathrm{ZnO}-\mathrm{WO}_{3}$ samples in $0.5 \mathrm{~mol} / \mathrm{L} \mathrm{Na} \mathrm{SO}_{4}$ aqueous solution at a fixed frequency of $1000 \mathrm{~Hz}$. (c) Schematic diagram illustrating the principle of charge transfer between $\mathrm{ZnO}$ and $\mathrm{ZnO}-\mathrm{WO}_{3}(3 \%)$. 


\section{Graphical Abstract}

Chin. J. Catal., 2018, 39: 54-62 doi: 10.1016/S1872-2067(17)62977-2

High photocatalytic activities of zinc oxide nanotube arrays modified with tungsten trioxide nanoparticles

Yawen Li, Yuzhen Bu, Qian Liu, Xia Zhang, Junli Xu* Northeastern University

$\mathrm{ZnO}$ nanotubes loaded with $\mathrm{WO}_{3}$ particles exhibited enhanced photocatalytic activity for the degradation of the herbicide chlorinated phenoxyacetic acid because of the improved separation of photogenerated charges and visible light absorption.

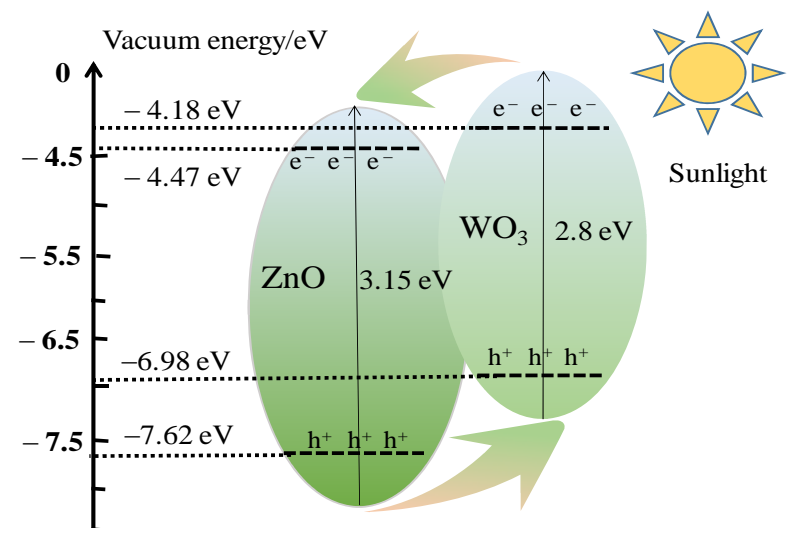

\section{References}

[1] E. Grabińska-Sota, E. Wisniowska, J. Kalka, Crop Protection, 2003, 22, 355-360.

[2] A. Lopze-Pineiro, D. Pena, A. Albarran, J. Sanchez-Lerena, D. Becerra, J. Contam. Hydrol., 2013, 152, 137-146.

[3] M. R. Hoffmann, S. T. Martin, W. Choi, D. W. Bahnemann, Chem. Rev., 1995, 95, 69-96.

[4] A. Zaleska, J. Hupka, M. Wiergowski, M. Biziuk, J. Photochem. Photobiol. A, 2000, 135, 213-220.

[5] S. O. Fatin, H. N. Lim, W. T. Tan, N. M. Huang, Int. J. Electrochem. Sci., 2012, 7, 9074-9084.

[6] A. Akyol, H. C. Yatmaz, M. Bayramoglu, Appl. Catal. B, 2004, 54, 19-24.

[7] F. A. Catano, S. H. Valencia, E. A. Hincapie, G. M. Restrepo, J. M. Marin, Lat. Am. Appl. Res., 2012, 42, 33-38.

[8] J. Z. Huang, S. Liu, L. Kuang, Y. D. Zhao, T. Jiang, S. Y. Liu, X. J. Xu, J. Environ. Sci, 2013, 25, 2487-2491.

[9] S. M. Lam, J. C. Sin, A. Z. Abdullah, A. R. Mohamed, J. Colloid Interface Sci., 2015, 450, 34-44.

[10] Z. Q. Liu, X. H. Xie, Q. Z. Xu, S. H. Guo, N. Li, Y. B. Chen, Y. Z. Su, Electrochim. Acta, 2013, 98, 68-273.

[11] C. Q. Zhu, B. A. Lu, Q. Su, E. Q. Xie, W. Lan, Nanoscale, 2012, 4, 3060-3064.

[12] D. D. Nguyen, D. T. Do, X. H. Vu, D. V. Dang, D. C. Nguyen, Adv. Nat. Sci.: Nanosci. Nanotechnol., 2016, 7, 015004/1-0150041/6.

[13] Y. Miao, H. J. Zhang, S. Yuan, Z. Jiao, X. D. Zhu, J. Colloid Interface Sci., 2016, 462, 9-18.

[14] Z. Lou, J. N. Deng, L. L. Wang, L. J. Wang, T. Fei, T. Zhang, Sens. Actuators, $B, 2013,176,323-329$.

[15] Y. Sun, G. M. Fuge, N. A. Fox, D. J. Riley, M. N. R. Ashfold, Adv. Mater., 2005, 24, 77-81.

[16] J. Elias, R. Tean-Zaera, G. Y. Wang, C. Levy-Clement, Chem. Mater., 2008, 20, 6633-6637.

[17] X. Y. Gan, X. M. Li, X. D. Gao, W. D. Yu, J. Alloys Compd., 2009, 481, 397-401.

[18] J. Y. Yang, Y. Lin, Y. M. Meng, Y. H. Liu, Ceram. Int., 2012, 38, 4555-4559.

[19] C. H. Hsu, D. H. Chen, Int. J. Hydrogen Energy, 2011, 36, 15538-15547.

[20] A. I. Hochbaum, P. D. Yang, Chem. Rev., 2010, 110, 527-546.
[21] C. L. Yu, W. Q. Zhou, J. C. Yu, H. Liu, L. F. Wei, Chin. J. Catal., 2014, 35, 1609-1618

[22] J. D. Li, C. L. Yu, W. Fang, L. H. Zhu, W. Q. Zhou, Q. Z. Fan, Chin. J. Catal., 2015, 36, 987-993

[23] H. B. He, S. S. Xue, Z. Wu, C. L. Yu, K. Yang, G. M. Peng, W. Q. Zhou, D. H. Li, Chin. J. Catal., 2016, 37, 1841-1580

[24] X. H. Zhang, X. H. Lu, Y. Q. Shen, J. B. Han, L. Y. Yuan, L. Gong, Z. Xu, X. D. Bai, M. Wei, Y. X. Tong, Y. H. Gao, J. Chen, J. Zhou, Z. L. Wang, Chem. Commun., 2011, 47, 5804-5806.

[25] H. D. Zheng, J. Z. Ou, M. S. Strano, R. B. Kaner, A. Mitchell, K. Kalantar-Zadeh, Adv. Funct. Mater., 2011, 21, 2175-2196.

[26] D. Li, H. Haneda, J. Photochem. Photobiol. A, 2003, 160, 203-212.

[27] D. Li, H. Haneda, N. Ohashi, S. Hishita, Y. Yoshikawa, Catal. Today, 2004, 93, 895-901.

[28] C. L. Yu, K. Yang, Q. Shu, C. Yu Jimmy, F. F. Cao, X. Li, Chin. J. Catal., 2011, 32, 555-565.

[29] J. Xie, Z. Zhou, Y. W. Lian, Y. J. Hao, X. Y. Liu, M. X. Li, Y. Wei, Ceram. Int., 2014, 40, 12519-12524.

[30] S. Adhikari, D. Sarkar, G. Madras, RSC Adv., 2015, 5, 11895-11904.

[31] L. Y. Huang, H. Xu, Y. P. Li, H. M. Li, X. N. Cheng, J. X. Xia, Y. G Xu, G. B Cai, Dalton Trans., 2013, 42, 8606-8616.

[32] S. Sharma, S. Singh, N. Khare, Int. J. Hydrogen Energy, 2016, 41, 21088-21098.

[33] K. Z. Lv, J. Li, X. X. Qing, W. Z. Li, Q. Y. Chen, J. Hazard. Mater., 2011, 189, 329-335.

[34] S. Y. Zhang, H. Li, Z. F. Yang, J. Alloys Compd., 2017, 722, 555-563.

[35] Y. P. He, Z. Y. Wu, L. M. Fu, C. R. Li, Y. M. Miao, L. Cao, H. M. Fan, B. S. Zou, Chem. Mater., 2003, 15, 4039-4045.

[36] J. C. Sin, S. M. Lam, K. T. Lee, A. R. Mohamed, Mater. Sci. Semicond. Process., 2013, 16, 1542-1550.

[37] A. K. Sajjad, S. Shamaila, B. Z. Tian, F. Chen, J. L. Zhang, Appl. Catal. $B, 2009,91,397-405$.

[38] M. V. Limaye, S. B. Singh, R. Das, P. Poddar, S. K. Kulkarni, J. Solid State Chem., 2011, 184, 391-400.

[39] D. Y. Fu, G. Y. Han, C. F. Meng, Mater. Lett., 2012, 72, 53-56.

[40] B. Subash, B. Krishnakumar, B. Sreedhar, M. Swaminathan, M. Shanthi, Superlattices Microstruct., 2013, 54, 155-171.

[41] S. Stojadinovi, R. Vasili, N. Radi, N. Tadi, P. Stefanov, B. Grbic, Appl. Surf. Sci., 2016, 377, 37-43.

[42] R. Mohammadzadeh. Kakhki, R. Tayebee, F. Ahsani, J. Mater. Sci. Mater. Electron., 2017, 28, 5941-5952.

[43] J. D. Ye, S. L. Gu, F. Qin, S. M. Zhu, S. M. Liu, X. Zhou, W. Liu, L. Q. Hu, 
R. Zhang, Y. Shi, Y. D. Zheng, Appl. Phys. A, 2005, 81, 759-762.

[44] S. K. Panda, N. Singh, J. Hooda, C. Jacob, Cryst. Res. Technol., 2008, $43,751-755$.
[45] H. J. Zhang, G. H. Chen, D. W. Bahnemann, J. Mater. Chem., 2009, 19, 5089-5121.

[46] Y. Xu, M. A. A. Schoonen, Am. Mineral., 2000, 85, 543-556.

\title{
$\mathrm{WO}_{3}$ 纳米颗粒修饰 $\mathrm{ZnO}$ 纳米管的光催化性能
}

\author{
李亚文, 布玉珍, 刘 倩, 张 霞, 徐君莉 \\ 东北大学理学院, 辽宁沈阳 110004
}

\begin{abstract}
摘要: 二甲四氯钠(MCPA-Na) 是一种广泛用于牧场和果园的除草剂, 但由于其生物降解性极低, 已成为地下水和浅水中的 主要污染物. 研究发现, 半导体可以有效地辅助降解转化危险化学品. ZnO纳米管因其中空结构和较大的比表面积, 而在 光催化降解有机物方面备受关注. 但是, $\mathrm{ZnO}$ 只能吸收紫外光, 如果将其与窄带隙半导体进行复合, 可以有效降低带隙, 增 强其在可见光区域的光吸收, 表现出更好的光催化性能. $\mathrm{WO}_{3}$ 是一种具有稳定物理化学性质及耐光腐蚀窄带隙半导体. 采 用 $\mathrm{WO}_{3}$ 修饰 $\mathrm{ZnO}$ 纳米管, 能扩展 $\mathrm{ZnO}$ 吸收光的范围以及提高 $\mathrm{ZnO}$ 纳米管的耐光腐蚀性能. 本文首先通过电化学合成的方法 制备了 $\mathrm{ZnO}$ 纳米管, 然后按照不同的 $\mathrm{W} / \mathrm{Zn}$ 摩尔比将 $\left(\mathrm{NH}_{4}\right)_{6} \mathrm{H}_{2} \mathrm{~W}_{12} \mathrm{O}_{40} \cdot \mathrm{XH}_{2} \mathrm{O}$ 滴加在纳米管表面, 并在 $450{ }^{\circ} \mathrm{C}$ 下退火 $2 \mathrm{~h}$ 制得 $\mathrm{ZnO}-\mathrm{WO}_{3}$ 纳米管阵列. 研究了不同 $\mathrm{WO}_{3}$ 含量的 $\mathrm{ZnO}-\mathrm{WO}_{3}$ 纳米管光催化降解 $\mathrm{MCPA}-\mathrm{Na}$ 性能, 并且通过 $\mathrm{X}$ 射线光电子能谱 (XPS)、傅里叶红外光谱仪(FTIR)、紫外可见光谱(UV-Vis) 和光致发光光谱(PL)等手段研究了复合 $\mathrm{WO}_{3}$ 纳米颗粒后 $\mathrm{ZnO}$ 纳 米管半导体光催化性能提高的原因.

XPS结果表明, $\mathrm{W}$ 元素在 $\mathrm{ZnO}-\mathrm{WO}_{3}$ 纳米管阵列中以 $\mathrm{W}^{6+}$ 的形式存在. FTIR结果表明, 复合 $\mathrm{WO}_{3}$ 后的 $\mathrm{ZnO}-\mathrm{WO}_{3}$ 复合半导 体上比纯 $\mathrm{ZnO}$ 纳米管表面具有更多的 $\mathrm{OH}^{-}$基团. 由于 $\mathrm{OH}^{-}$可以捕获光生空穴, 并转化为具有反应活性的· $\mathrm{OH}$ 自由基, 因此复 合 $\mathrm{WO}_{3}$ 能在一定程度上提高 $\mathrm{ZnO}$ 纳米管的光催化活性. UV-Vis结果表明, $\mathrm{WO}_{3}$ 的复合使得光谱发生明显红移, 但随着 $\mathrm{WO}_{3}$ 含量的增加, $\mathrm{ZnO}-\mathrm{WO}_{3}$ 的吸光度明显增加. 另外, PL结果表明, 适当的复合 $\mathrm{WO}_{3}$ 可以抑制光生电子-空穴的复合. 这是因为 $\mathrm{W}^{6+}$ 和晶格氧的相互作用产生了较高不饱和键和表面缺陷, 而表面缺陷可以作为光生载流子的陷阱, 促进了光生电子和空 穴的分离, 因而光催化性能提高.

在模拟太阳光下研究了不同 $\mathrm{WO}_{3}$ 含量的 $\mathrm{ZnO}$ 纳米管对光催化降解MCPA-Na溶液的性能. 发现 $\mathrm{W} / \mathrm{Zn}$ 摩尔比为 $3 \%$ 的 $\mathrm{ZnO}-\mathrm{WO}_{3}$ 样品表现出最好的光催化活性, $200 \mathrm{~min}$ 内其降解率为 $98.5 \%$. 与纯 ZnO纳米管相比, 其光催化循环性能也有所提


于 $\mathrm{WO}_{3}$ 导带位置和价带位置都比 $\mathrm{ZnO}$ 的更高, $\mathrm{WO}_{3}$ 上产生的光生电子会向 $\mathrm{ZnO}$ 的导带移动, 而 $\mathrm{ZnO}$ 光生空穴向 $\mathrm{WO}_{3}$ 的价带 移动, 从而促使光生电子和空穴的分离, 提高了光催化性能. 但是如果 $\mathrm{WO}_{3}$ 复合的量太大, 则在 $\mathrm{ZnO}$ 纳米管上分散性不好, 反而成为光生空穴和电子复合中心, 导致其光催化活性降低.
\end{abstract}

关键词: 氧化锌纳米管; 三氧化铇; 光催化降解; 电沉积; 电学性质

收稿日期: 2017-07-09. 接受日期: 2017-11-12. 出版日期: 2018-01-05.

*通讯联系人. 电话/传真: (024)83684533; 电子信箱: jlxu@mail.neu.edu.cn

基金来源：国家自然科学基金(51574071).

本文的电子版全文由Elsevier出版社在ScienceDirect上出版(http://www.sciencedirect.com/science/journal/18722067). 